\title{
PENDETEKSIAN DERAU CITRA SECARA OTOMATIS MENGGUNAKAN TEKNIK JARINGAN SYARAF TIRUAN
}

Oleh :

Julsam

Staf Pengajar Politeknik Negeri Padang

\begin{abstract}
This research is application of neural network technique to optimize convolution operation using mask $3 \times 3$ to omit the image blurring effect. This neural network consists of three layers. They are input layer (9 neuron inputs), output layer (1 output neuron) and hidden layer. Each layer is applied to 3, 5 and 7 neuron using back propagation technique. The result shows the using five neurons to hidden layer give the highest value of sound pixel recognizing (76.47\%)
\end{abstract}

Key Word : Image, convolution, neural network, back propagation

\section{PENDAHULUAN}

Citra (image) dapat mengalami gangguan derau (noise). Gangguan pada citra ini dapat dilihat sebagai variasi intensitas pixel yang tidak berkorelasi baik dengan pixel-pixel tetanggamya. Perbaikan citra dengan proses pelembutan citra yang salah satunya dilakukan dengan menggunakan metode konvolusi (Mask) yaitu dengan operasi penapisan menggunakan penapis linier. Operasi penapisan menyebabkan efek pemerataan deajat keabuan, sehingga citra yang diperoleh terlihat lebih kabur kontrasnya yang dikenal sebagai efek pengabuan (blurring).[Rinaldi Munir, 2004] Jika proses konvolusi hanya diterapkan pada pixel yang membutuhkan saja, maka efek blurring dapat dihindarkan.

Berdasarkan gambaran ini penulis mencoba melakukan pengembangan dari metode konvolusi ini dengan melakukan pemeriksaan kondisi píxel tetangga dari suatu píxel yang akan dikonvolusi. Jika diperlukan konvolusi barulah proses Masking dilakukan sehingga akan dihasilkan pelembutan citra yang optimal. Pemeriksaan píxel sebelum konvolusi perlu dilakukan dengan cara mencedaskan komputer seperti cerdasnya manusia dalam mengamati citra. Pencerdasan ini dilakukan dengan teknik jaringan syaraf tiruan.

\section{Perumusan Masalah}

Pelembutan citra akan dilakukan dengan cara konvolusi (Mask) yang dikembangkan dengan kemampuan kecedasan (kecerdasan buatan) dalam menentukan píxel yang perlu dikonvolusi. Dari uraian yang diberikan pada latar belakang masalah diatas dapat dirumuskan permasalahannya sebagai berikut :

- Bagaimana mengatasi efek blurring yang terjadi pada proses konvolusi sebuah citra.

- Bagaimana merancang model jaringan syaraf tiruan untuk mendeteksi keberadaan derau

- Bagaimana menerapkan propagasi balik sebagai algoritma pembelajaran

- Bagaimana menerapkan jaringan syaraf tiruan untuk mendeteksi pixel yang perlu dikonvolusi. 
- Apakah dengan jaringan syaraf tiruan ini derau pada citra dapat dideteksi secara otomatis.

\section{Tujuan Penelitian}

- Mengembangkan algoritma konvolusi dengan mengevaluasi píxel yang ditinjau terhadap píxel tetangga.

- Membangun model jaringan syaraf tiruan untuk mengoptimalkan operasi pelembutan citra

- Membangun sistem pelembutan citra yang menerapkan teknik jaringan syaraf tiruan.

- Mengevaluasi kinerja pelembutan citra konvensional dengan bantuan jaringan syaraf tiruan.

\section{TINJAUAN PUSTAKA Citra Digital}

Citra (image) adalah gambar pada bidang dwimatra (dua dimensi) [Rinaldi M, 2004]. Gambar 2.1.a adalah contoh dari sebuah citra yaitu citra kupukupu. Intensitas cahaya (brightness) bernilai antara 0 sampai dengan tak berhingga. Citra digital adalah citra kontiniu yang diubah ke dalam bentuk diskrit baik koordinat maupun intensitas cahayanya. Untuk citra dengan 256 derajat bilangan bulat antara 0 .. 255.[Rafael CG et keabuan, nilai setiap elemen matriks adalah al, 2002]

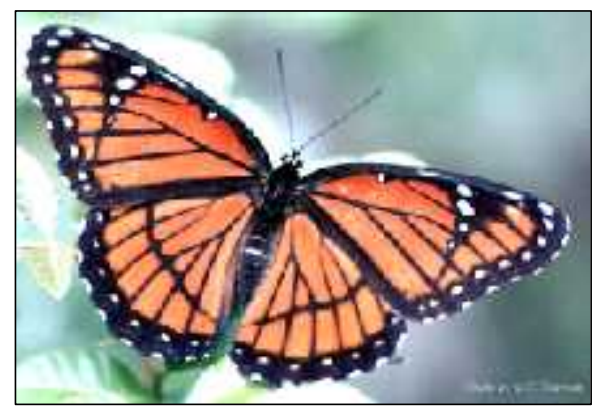

a.

\section{Gambar 1.a. Citra Kupu-Kupu \\ b. Citra dengan derau}

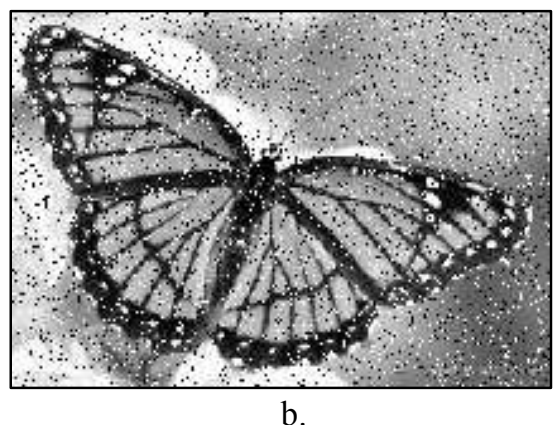

Citra digital yang berukuran $\mathrm{M} \times \mathrm{N}$ sering dinyatakan dengan matriks yang berukuran $\mathrm{M}$ baris dan $\mathrm{N}$ kolom sebagai berikut :

$f(x, y)=\left[\begin{array}{cccc}f(0,0) & f(0,1) & \ldots & f(0, N-1) \\ f(1,0) & f(1,1) & \ldots & f(1, N-1) \\ : & : & : & : \\ f(M-1,0) & f(M-1,1) & \ldots & f(M-1, N-1)\end{array}\right]$

Indeks baris (i) dan indeks kolom (j) menyatakan suatu koordinat titik pada citra sedangkan $\mathrm{f}(\mathrm{i}, \mathrm{j})$ merupakan intensitas (derajat keabuan) pada titik $(\mathrm{i}, \mathrm{j})$.

\section{Operasi Penghilangan Derau (Pelembutan Citra)}

Derau pada citra merupakan pixel yang nilai derajat keabuannya mempunyai variasi intensitas píxel yang tidak berkorelasi baik dengan pixel-pixel tetanggamya. Hal ini dapat dilihat sebagai bercak-bercak pada citra. Contoh citra yang mengandung derau dapat dilihat pada gambar 1.b

\section{Konvolusi}

Konvolusi merupakan penjumlahan dari perkalian setiap titik pada kernel dengan setiap titik pada fungsi masukan. Kernel dioperasikan secara bergeser pada fungsi masukan $\mathrm{f}(\mathrm{x})$. Jumlah perkalian setiap titik pada kedua fungsi tersebut merupakan hasil konvolusi yang dinyatakan dengan $\mathrm{h}(\mathrm{x})$. Ilustrasi konvolusi ditunjukkan pada gambar 2 . 


\section{Operasi pelembutan citra}

Operasi pelembutan citra dimaksudkan untuk menekan derau (noise) yang terdapat pada citra. Operasi pelembutan pada ranah spasial dilakukan mengganti intensitas suatu pixel dengan rata-rata dari nilai pixel tersebut dan nilai píxel-pixel berukuran $\mathrm{NxM}$ píxel tetangganya. Sebuah citra $\mathrm{f}(\mathrm{x}, \mathrm{y})$

mempunyai hasil pelembutannya sebagai berikut :

$$
g(x, y)=\frac{1}{d} \sum_{r=m_{1}}^{m_{2}} \sum_{s=n_{1}}^{n_{2}} f(x+r, y+s)
$$

di mana : $\mathrm{d}=$ jumlah píxel yang terlibat dalam perhitungan rata-rata.

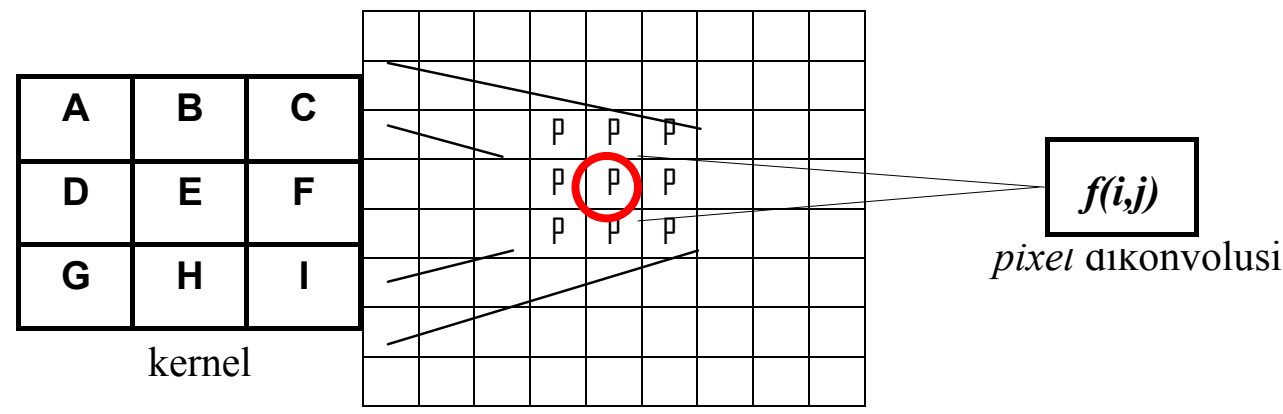

$$
f(i, j)=A p_{1}+B p_{2}+C p_{3}+D p_{4}+E p_{5}+F p_{6}+G p_{7}+H p_{8}+I p_{9}
$$

Gambar 2. Ilustrasi proses konvolus

Operasi perata-rataan dapat dipandang sebagai konvolusi antara citra $\mathrm{f}(\mathrm{x}, \mathrm{y})$ dengan penapis $\mathrm{h}(\mathrm{x}, \mathrm{y})$ yang disebut penapis rata-rata (mean filter) yang dikenal sebagai Mask

$$
g(x, y)=f(x, y) * h(x, y)
$$

Penapis $h$ disebut penapis rata-rata (mean filter) adalah merupakan matriks yang hasil penjumlahan komponenkomponennya bernilai 1 , seperti contoh berikut untuk penapis $3 \times 3$.

$\left[\begin{array}{ccc}1 / 9 & 1 / 9 & 1 / 9 \\ 1 / 9 & \bullet 1 / 9 & 1 / 9 \\ 1 / 9 & 1 / 9 & 1 / 9\end{array}\right]$

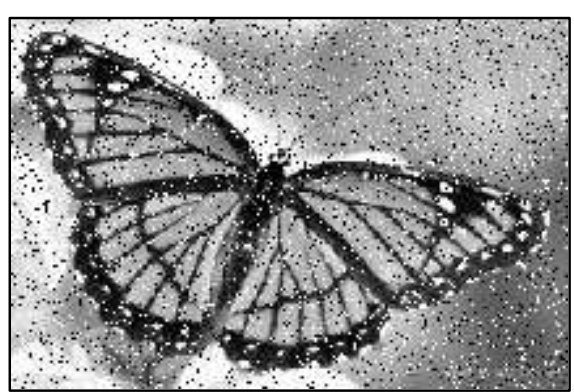

Sebelum penapisan

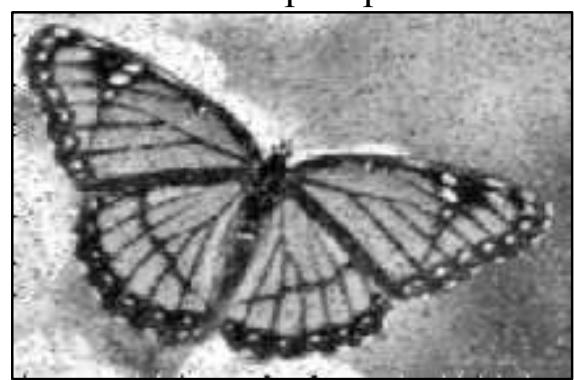

Sesudah penapisan

Gambar 3. Hasil penapisan derau citra 
Operasi penapisan (pelembutan) citra ini mempunyai efek pemerataan derajat keabuan sehingg gambar yang diperoleh tampak lebihkabur kontrasnya. Efek pengaburan ini yang disebut efek blurring. Contoh citra yang kabur akibat penapisan dapat dilihat pada gambar 3 .

\section{Model Jaringan Syaraf Tiruan}

Jaringan syaraf tiruan (JST) merupakan model yang dikembangkan berdasarkan prinsip struktur jaringan biologi syaraf manusia. Gambar 4. merupakan contoh

Gambar 5. melukiskan sebuah model komputasi neuron buatan yang sederhana (perceptron) yang mulanya diperkenalkan oleh McCulloch. Untuk membatasi nilai pada output neuron, arsitektur hubungan jaringan syaraf tiruan Setiap neuron saling terhubung dan setiap hubungannya mempunyai nilai pemberat masing-masing

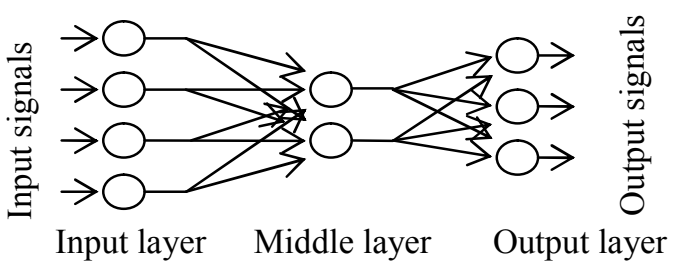

Gambar 4. Contoh arsitektur jaringan syaraf tiruan [Mickael N, 2002]

nilai jaringan dilewatkan pada sebuah fungsi aktivasi yang akan membatasinya pada nilai ambang (threshold). Nilai yang dihasilkan oleh fungsi aktivasi merupakan nilai neuron karena merupakan keluaran suatu unit neuron.

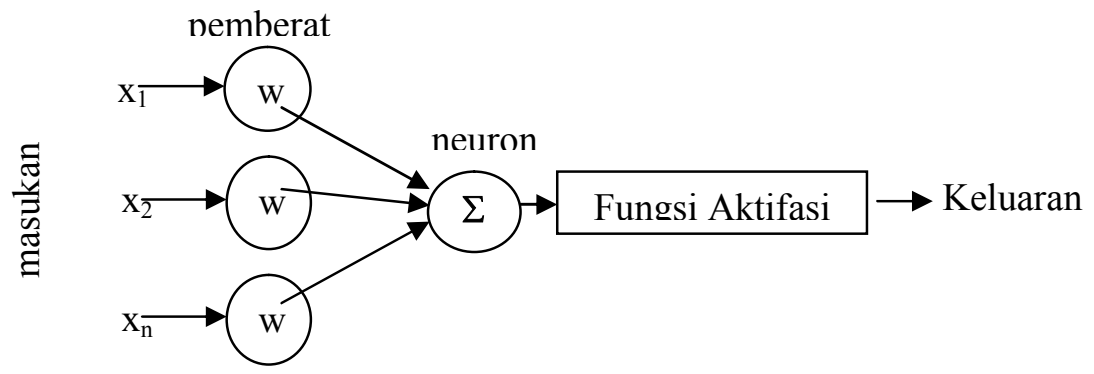

Gambar 5. Model tiruan sebuah neuron [Mauridhi HP, 2002]

Neuron menghitung jumlah pemberatnya dan membandingkan hasilnya dengan nilai threshold, $\theta$. Jika hasilnya lebih kecil dari nilai threshold keluaran neuron adalah -1, sebaliknya jika hasilnya lebih besar atau sama dengan threshold, neuron menjadi aktif dan keluaran neuron bernilai +1 . Secara matematis digambarkan sebagai berikut : [Michael N, 2002]

$$
\begin{aligned}
& X=\sum_{i=1}^{n} x_{i} w_{i} \\
& Y^{s i g n}= \begin{cases}+1 & \text { jika } X \geq \theta \\
-1 & \text { jika } X<\theta\end{cases}
\end{aligned}
$$

dimana :

$\mathrm{X}=$ jumlah perkalian masukan dan pemberat ke neuron,

$\mathrm{xi}=$ nilai masukan ke $\mathrm{i}$,

$\mathrm{wi}=$ nilai pemberat input ke $\mathrm{i}$,

$\mathrm{n}=$ jumlah jumlah neuron masukan

$\mathrm{Y}=$ keluaran dari neuron

Jenis fungsi aktifasi yang dijelaskan diatas adalah sign function. Keluaran aktual dari neuron yang diaktifasi dengan sign function dapat dinyatakan sebagai :

$$
Y=\operatorname{sign}\left[\sum_{i=1}^{n} x_{i} w_{i}-\theta\right]
$$




\section{Mengaktifkan Jaringan Saraf Tiruan}

Mengaktifkan jaringan saraf tiruan berarti mengaktifkan seluruh neuron yang terdapat pada jaringan tersebut. Ada beberapa fungsi lain yang dapat dipakai sebagai pengaktif neuron, seperti fungsi unit step, impulse sigmoid dan fungsi linier.

Fungsi sigmoid terdiri dari dua jenis, yaitu unipolar dan bipolar. Persamaan fungsi sigmoid unipolar adalah

$$
y^{\text {sigmoid }}=\left(\frac{1}{1+e^{-x}}\right)
$$

Kurva fungsi sigmoid unipolar ini digambarkan pada gambar 6 .

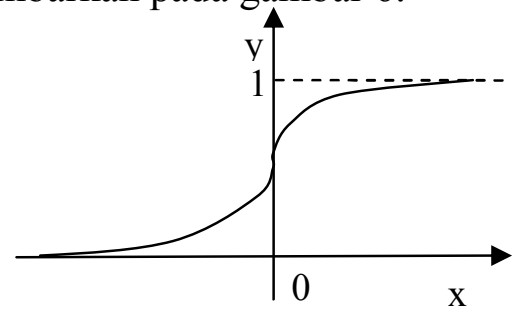

Gambar 6. Fungsi sigmoid unipolar

Untuk fungsi sigmoid bipolar dinyatakan sebagai :

$$
y=\left(\frac{1-e^{-f(x)}}{1+e^{-f(x)}}\right)
$$

dan digambarkan sebagai berikut :

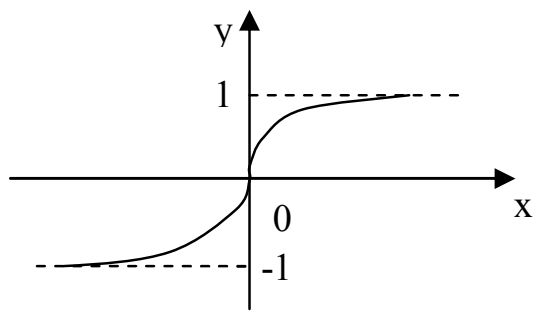

Gambar 7. Fungsi sigmoid bipolar
Fungsi aktifasi step dan juga sign disbut juga hard limit function dan sering digunakan dalam pengambilan keputusan neuron untuk klasifikasi dan pengenalan pola. Kurva fungsi aktifasi step dan sign dibambarkan pada gambar 8.

Pernyataan matematis untuk fungsi Sign telah dijelaskan pada bagian sebelumnya sedangan untuk fungsi aktifasi Step adalah

$$
Y^{\text {step }}= \begin{cases}1, & \text { jika } X \geq 0 \\ 0, & \text { jika } X<0\end{cases}
$$
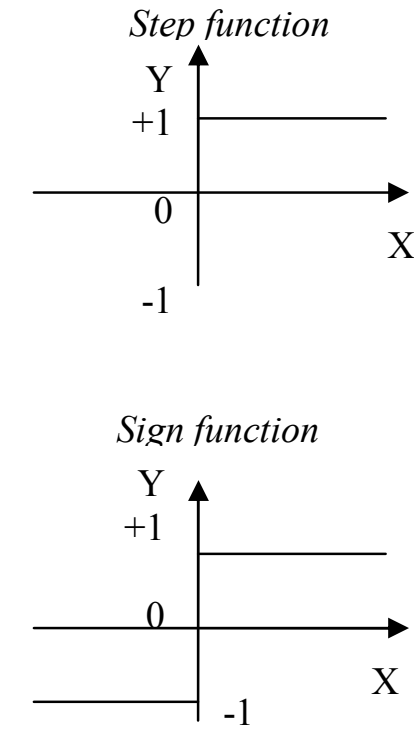

Gambar 8. Fungsi aktifasi Step dan Sign

Selanjutnya fungsi aktifasi linier digambarkan pada gambar 9, dengan pernyataan matematisnya sebagai berikut

$Y^{\text {linier }}=X$ 


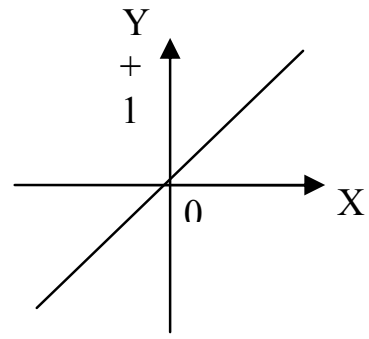

Gambar 9. Fungsi aktifasi Linier

\section{METODE PENELITIAN Alat Bantu Penelitian}

Untuk menerapkan algoritma yang dikembangkan ini diperlukan sejumlah alat bantu berupa perangkat keras dan perangkat lunak. Perangkat keras yang dibutuhkan adalah 1 set komputer Pentium IV dengan memori sebesar 512 MB untuk memudahkan eksekusi program. Di samping itu diperlukan alat bantu berupa perangkat lunak yaitu Matlab.

Matlab digunakan untuk melakukan pembentukan derau pada citra serta melakukan pembelajaran pembuktian akurasi keluaran jaringan syaraf tiruan. Selain itu Matlab juga digunakan untuk pembuktian algoritma pejernihan citra yang disusun.

\section{Metode Pengujian}

Seperti telah dijelaskan bahwa penelitian ini bertujuan untuk mengembangkan algoritma penjernihan citra yang optimal dengan teknik jaringan syaraf tiruan. Pengujian dilakukan dengan mengoperasikan scrip aplikasi yang dikembangkan dengan bantuan Matlab

\section{HASIL DAN PEMBAHASAN}

Data penelitian diambilkan dari contoh beberapa citra yang ada yang mengandung derau seperti pada gambar. Gambaran dari data pixel citra yang mengandung derau ini dapat dilihat pada tabel 1. yang diperoleh menggunakan Matlab.

Citra yang dianalisa adalah citra 8 bit dengan 256 derajat keabuan. Warna derajat keabuan ini bernilai antara 0 (merupakan warna putih) hingga 255 yang merupakan warna hitam). Kalau diperhatikan dari citra asal data diatas terlihat jelas bahwa warna derau itu adalah putih (atau mendekati putih) dan hitam (atau mendekati hitam). Berdasarkan tabel 1 posisi derau ini jelas terlihat dengan nilai 0 atau 255 karena sangat kontras dengan nilai pixel tetangga sekelilingnya.

Jaringan syaraf tiruan yang akan digunakan pada penelitian ini adalah mempunyai 9 masukan dan 1 keluaran. Ke 9 masukan ini merupakan nilai dari setiap matriks $3 \times 3$ yang diambil pada data asal pada tabel 4.1 di mana 1 keluaran adalah untuk mendapatkan keputusan bagi pixel tengah dari matriks tersebut, apakah perlu dikonvolusi atau tidak. Selanjutnya dilakukan penyusunan data masukan untuk jaringan syaraf tiruan.

Penyusunan data masukan untuk jaringan syaraf tiruan ini dilakukan dengan mengelompokkan data pada tabel 4.1 berdasarkan pola matriks $3 \times 3$ seperti contoh berikut yang diambil pada baris 4, 5 dan 6 , kolom 1, 2 dan 3 :

Contoh data matrik $3 \times 3$ sebagai masukan ke jaringan syaraf tiruan:

\begin{tabular}{rrr}
\hline 21 & 23 & 50 \\
72 & 255 & 60 \\
244 & 255 & 51 \\
\hline
\end{tabular}

Berdasarkan matriks data tabel 1 yang diperoleh ini disusun masukan untuk jaringan syaraf tiruan dengan susunan data baris pertama, kedua dan ketiga disusun berjajar kekanan, sehingga sel tengah dari matriks $(2,2)$ berada ditengah data. Kemudian melihat 
kepada pola matriks ini ditetapkan target keluaran yang harus dicapai. Untuk contoh ini nilai sel $(2,2)$ adalah 255 berbeda kontras dengan nilai sel sekelilingnya, sehingga merupakan derau dan perlu dikonvolusi. Oleh karena itu target untuk contoh ini adalah 1 . Sebaliknya bila tidak perlu dikonvolusi, target ditetapkan bernilai 0. Berdasarkan contoh di atas, data masukan untuk jaringan syaraf tiruan disusun sebagai berikut :

\section{$\left[\begin{array}{lllllllll}21 & 23 & 50 & 72 & 255 & 60 & 244 & 255 & 51\end{array}\right]$}

Data yang lainya diperoleh dengan membentuk matriks baru setelah bergeser satu sel kekanan dan seterusnya hingga diperoleh sejumlah data. Seperti tabel 2.

\section{Pembangunan Jaringan Syaraf Tiruan}

Berdasarkan kasus yang akan diselesaikan ini dan penjelasn diatas, maka jaringan syaraf tiruan yang dibangun cukuplah terdiri dari 3 lapisan, dimana lapisan masukan mempunyai 9 neuron masukan, lapisan keluaran 1 neuron keluaran, sedangkan untuk lapisan tersembunyi akan digunakan 3, 5 dan 7 neuron dalam pengujiannya. Gambaran jaringan syaraf tiruan ini digambarkan pada gambar 10 .

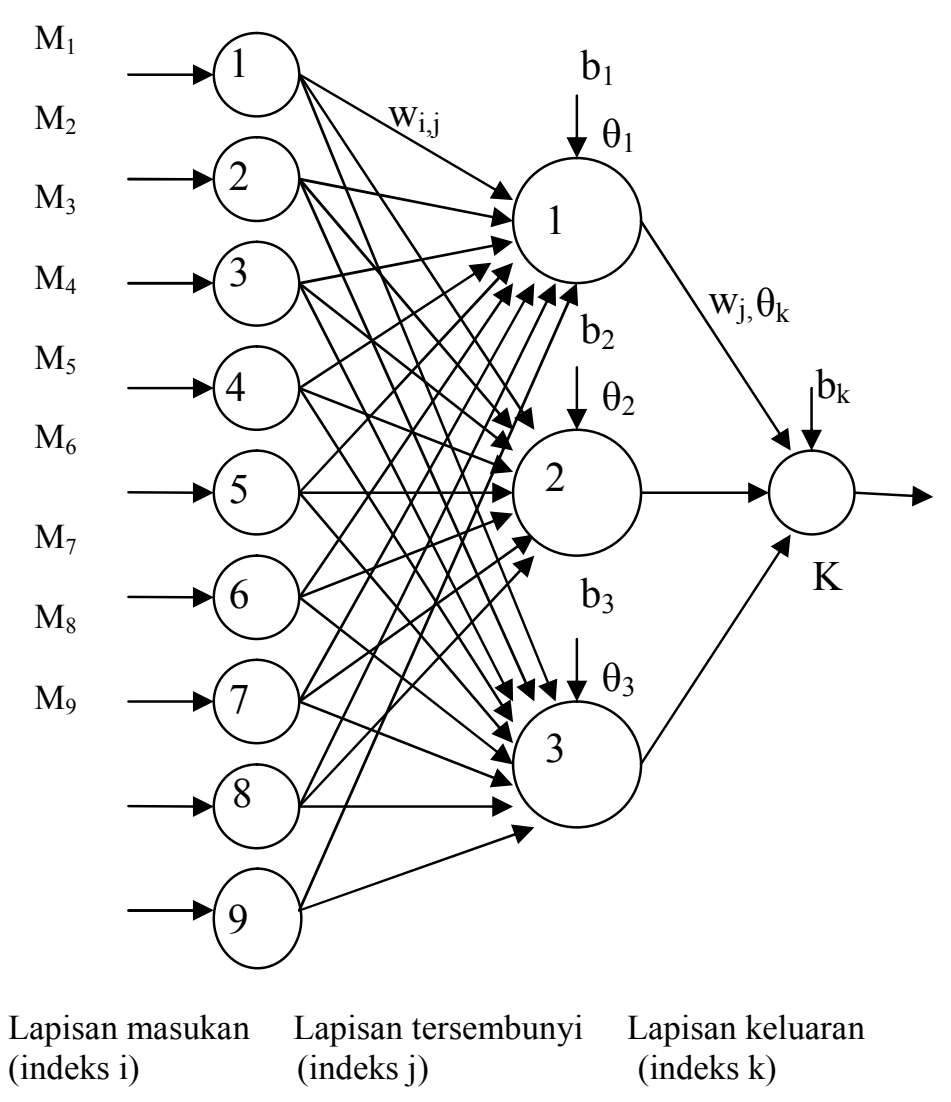

Gambar 10. Model Jaringan Syaraf Tiruan 
Tabel 1. Sebahagian Matriks Citra Butterfly Mengandung Derau

\begin{tabular}{|c|c|c|c|c|c|c|c|c|c|}
\hline & 1 & 2 & 3 & 4 & 5 & 6 & 7 & 8 & 9 \\
\hline 1 & 36 & 23 & 70 & 170 & 142 & 53 & 33 & 255 & 60 \\
\hline 2 & 27 & 38 & 32 & 35 & 43 & 42 & 36 & 42 & 70 \\
\hline 3 & 26 & 0 & 0 & 37 & 39 & 38 & 42 & 48 & 65 \\
\hline 4 & 21 & 23 & 50 & 65 & 45 & 33 & 41 & 66 & 66 \\
\hline 5 & 72 & 255 & 60 & 62 & 55 & 45 & 41 & 58 & 0 \\
\hline 6 & 244 & 255 & 51 & 42 & 49 & 52 & 0 & 47 & 49 \\
\hline 7 & 255 & 202 & 255 & 42 & 45 & 45 & 53 & 50 & 33 \\
\hline 8 & 255 & 162 & 44 & 54 & 43 & 41 & 72 & 255 & 255 \\
\hline 9 & 151 & 53 & 37 & 255 & 56 & 255 & 56 & 55 & 48 \\
\hline 10 & 255 & 48 & 35 & 49 & 81 & 75 & 56 & 48 & 57 \\
\hline 11 & 24 & 35 & 0 & 45 & 60 & 70 & 64 & 44 & 69 \\
\hline 12 & 29 & 30 & 57 & 60 & 48 & 47 & 52 & 255 & 111 \\
\hline 13 & 0 & 35 & 49 & 59 & 58 & 0 & 167 & 255 & 198 \\
\hline 14 & 32 & 33 & 47 & 48 & 75 & 196 & 255 & 245 & 161 \\
\hline 15 & 45 & 34 & 45 & 44 & 129 & 255 & 255 & 255 & 108 \\
\hline 16 & 45 & 45 & 60 & 255 & 168 & 255 & 184 & 110 & 0 \\
\hline 17 & 255 & 56 & 66 & 77 & 115 & 151 & 117 & 113 & 116 \\
\hline 18 & 73 & 0 & 84 & 95 & 98 & 108 & 114 & 115 & 0 \\
\hline 19 & 58 & 71 & 103 & 105 & 110 & 255 & 115 & 118 & 116 \\
\hline 20 & 89 & 92 & 101 & 112 & 114 & 115 & 114 & 118 & 118 \\
\hline
\end{tabular}

Tabel 2. Model Data Pengujian

\begin{tabular}{lllllllllll}
\hline & M1 & M2 & M3 & M4 & M5 & M6 & M7 & M8 & M9 & T \\
\hline 1 & 36 & 23 & 70 & 27 & 38 & 32 & 26 & 0 & 0 & 0 \\
2 & 23 & 70 & 170 & 38 & 32 & 35 & 0 & 0 & 37 & 0 \\
3 & 70 & 170 & 142 & 32 & 35 & 43 & 0 & 37 & 39 & 0 \\
4 & 170 & 142 & 53 & 35 & 43 & 42 & 37 & 39 & 38 & 0 \\
5 & 142 & 53 & 33 & 43 & 42 & 36 & 39 & 38 & 42 & 0 \\
6 & 53 & 33 & 255 & 42 & 36 & 42 & 38 & 42 & 48 & 0 \\
7 & 33 & 255 & 60 & 36 & 42 & 70 & 42 & 48 & 65 & 0 \\
8 & 27 & 38 & 32 & 26 & 0 & 0 & 21 & 23 & 50 & 1 \\
9 & 38 & 32 & 35 & 0 & 0 & 37 & 23 & 50 & 65 & 1 \\
10 & 32 & 35 & 43 & 0 & 37 & 39 & 50 & 65 & 45 & 0 \\
11 & 35 & 43 & 42 & 37 & 39 & 38 & 65 & 45 & 33 & 0 \\
12 & 43 & 42 & 36 & 39 & 38 & 42 & 45 & 33 & 41 & 0 \\
13 & 42 & 36 & 42 & 38 & 42 & 48 & 33 & 41 & 66 & 0 \\
14 & 36 & 42 & 70 & 42 & 48 & 65 & 41 & 66 & 66 & 0 \\
15 & 26 & 0 & 0 & 21 & 23 & 50 & 72 & 255 & 60 & 0 \\
16 & 0 & 0 & 37 & 23 & 50 & 65 & 255 & 60 & 62 & 0 \\
17 & 0 & 37 & 39 & 50 & 65 & 45 & 60 & 62 & 55 & 0 \\
18 & 37 & 39 & 38 & 65 & 45 & 33 & 62 & 55 & 45 & 0 \\
19 & 39 & 38 & 42 & 45 & 33 & 41 & 55 & 45 & 41 & 0 \\
20 & 38 & 42 & 48 & 33 & 41 & 66 & 45 & 41 & 58 & 0 \\
21 & 42 & 48 & 65 & 41 & 66 & 66 & 41 & 58 & 0 & 0 \\
22 & 21 & 23 & 50 & 72 & 255 & 60 & 244 & 255 & 51 & 1 \\
23 & 23 & 50 & 65 & 255 & 60 & 62 & 255 & 51 & 42 & 0
\end{tabular}




\begin{tabular}{|c|c|c|c|c|c|c|c|c|c|c|}
\hline 24 & 50 & 65 & 45 & 60 & 62 & 55 & 51 & 42 & 49 & 0 \\
\hline 25 & 65 & 45 & 33 & 62 & 55 & 45 & 42 & 49 & 52 & 0 \\
\hline 26 & 45 & 33 & 41 & 55 & 45 & 41 & 49 & 52 & 0 & 0 \\
\hline 27 & 33 & 41 & 66 & 45 & 41 & 58 & 52 & 0 & 47 & 0 \\
\hline 28 & 41 & 66 & 66 & 41 & 58 & 0 & 0 & 47 & 49 & 0 \\
\hline 29 & 72 & 255 & 60 & 244 & 255 & 51 & 255 & 202 & 255 & 1 \\
\hline 30 & 255 & 60 & 62 & 255 & 51 & 42 & 202 & 255 & 42 & 0 \\
\hline 31 & 60 & 62 & 55 & 51 & 42 & 49 & 255 & 42 & 45 & 0 \\
\hline 32 & 62 & 55 & 45 & 42 & 49 & 52 & 42 & 45 & 45 & 0 \\
\hline 33 & 55 & 45 & 41 & 49 & 52 & 0 & 45 & 45 & 53 & 0 \\
\hline 34 & 45 & 41 & 58 & 52 & 0 & 47 & 45 & 53 & 50 & 1 \\
\hline 35 & 41 & 58 & 0 & 0 & 47 & 49 & 53 & 50 & 33 & 0 \\
\hline 36 & 244 & 255 & 51 & 255 & 202 & 255 & 255 & 162 & 44 & 0 \\
\hline 37 & 255 & 51 & 42 & 202 & 255 & 42 & 162 & 44 & 54 & 1 \\
\hline 38 & 51 & 42 & 49 & 255 & 42 & 45 & 44 & 54 & 43 & 0 \\
\hline 39 & 42 & 49 & 52 & 42 & 45 & 45 & 54 & 43 & 41 & 0 \\
\hline 40 & 49 & 52 & 0 & 45 & 45 & 53 & 43 & 41 & 72 & 0 \\
\hline 41 & 52 & 0 & 47 & 45 & 53 & 50 & 41 & 72 & 255 & 0 \\
\hline 42 & 0 & 47 & 49 & 53 & 50 & 33 & 72 & 255 & 255 & 0 \\
\hline 43 & 255 & 162 & 44 & 151 & 53 & 37 & 255 & 48 & 35 & 0 \\
\hline 44 & 162 & 44 & 54 & 53 & 37 & 255 & 48 & 35 & 49 & 0 \\
\hline 45 & 44 & 54 & 43 & 37 & 255 & 56 & 35 & 49 & 81 & 1 \\
\hline 46 & 54 & 43 & 41 & 255 & 56 & 255 & 49 & 81 & 75 & 0 \\
\hline 47 & 43 & 41 & 72 & 56 & 255 & 56 & 81 & 75 & 56 & 1 \\
\hline 48 & 41 & 72 & 255 & 255 & 56 & 55 & 75 & 56 & 48 & 0 \\
\hline 49 & 72 & 255 & 255 & 56 & 55 & 48 & 56 & 48 & 57 & 0 \\
\hline 50 & 58 & 0 & 167 & 75 & 196 & 255 & 129 & 255 & 255 & 0 \\
\hline 51 & 0 & 167 & 255 & 196 & 255 & 245 & 255 & 255 & 255 & 0 \\
\hline 52 & 45 & 44 & 129 & 60 & 255 & 168 & 66 & 77 & 115 & 1 \\
\hline 53 & 44 & 129 & 255 & 255 & 168 & 255 & 77 & 115 & 151 & 0 \\
\hline 54 & 129 & 255 & 255 & 168 & 255 & 184 & 115 & 151 & 117 & 0 \\
\hline 55 & 255 & 56 & 66 & 73 & 0 & 84 & 58 & 71 & 103 & 1 \\
\hline 56 & 98 & 108 & 114 & 110 & 255 & 115 & 114 & 115 & 114 & 1 \\
\hline 57 & 112 & 114 & 115 & 114 & 0 & 116 & 115 & 115 & 115 & 1 \\
\hline 58 & 255 & 111 & 115 & 110 & 0 & 112 & 255 & 255 & 112 & 1 \\
\hline 59 & 104 & 102 & 103 & 255 & 101 & 0 & 97 & 97 & 98 & 0 \\
\hline 60 & 102 & 103 & 108 & 101 & 0 & 0 & 97 & 98 & 99 & 1 \\
\hline 61 & 103 & 108 & 109 & 0 & 0 & 108 & 98 & 99 & 101 & 1 \\
\hline 62 & 108 & 109 & 109 & 0 & 108 & 255 & 99 & 101 & 105 & 0 \\
\hline
\end{tabular}

Jaringan syaraf tiruan yang digunakan ini dilatih menggunakan teknik propagasi balik (back propagation). Pembelajaran pada jaringan lapisan majemuk ini negggunakan cara yang sama dengan perceptron. Pada perceptron hanya ada satu pemberat untuk setiap masukan, akan tetapi pada lapisan majemuk ini setiap masukan mempunyai banyak pemberat.

Pembelajaran ini berlangsung dalam dua fase. Pertama pelatihan pola masukan diberikan ke lapisan masukan jaringan. Jaringan akan meneruskan pola masukan ini dari lapisan ke lapisan hingga dihasilkan pola keluaran, dan dikenal dengan Feedforward. Bila pola keluaran berbeda dengan keluaran yang 
diharapkan, kesalahannya dihitung dan dialirkan kearah balik (backward). Pemberat yang telah diset dimodifikasi selama kesalahan masih ada.

Sinyal-sinyal masukan dilewatkan melalui fungsi aktifasi. Fungsi aktifasi yang sering digunakan adalah fungsi aktifasi sigmoid. Rober C. William (1995) menggunakan fungsi aktifasi sigmoid pada jaringan syaraf feedforward untuk menyelesaikan

\section{HASIL DAN PEMBAHASAN}

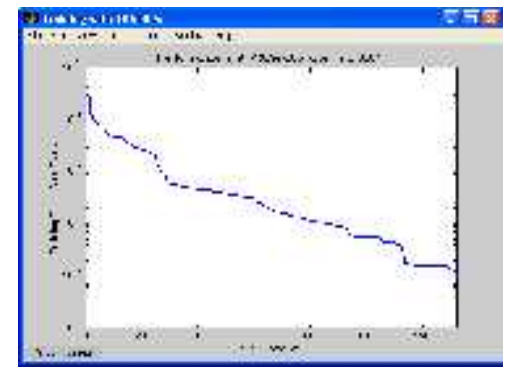

a. Dengan fungsi performansi MSE regresi beberapa fungsi yang tidak diketahui. Seperti telah dituliskan pada persamaan 2.4 fungsi aktifasi sigmoid adalah :

$$
Y^{\text {sigmoid }}=\frac{1}{1+e^{-x}}
$$

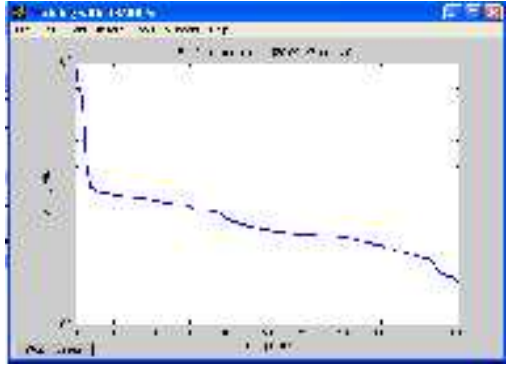

b. Dengan fungsi performansi SSE

Gambar 11. Performansi pelatihan untuk 3 Neuron pada lapisan tersembunyi

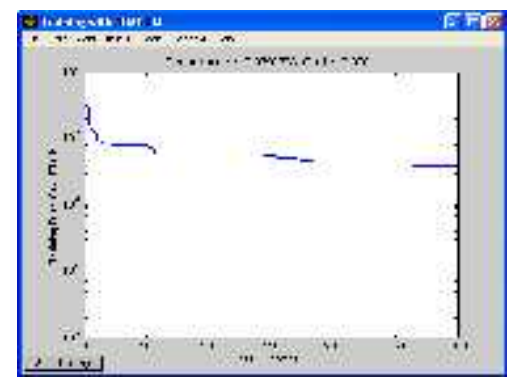

a. Dengan 5 neuron pada lapisan tersembunyi

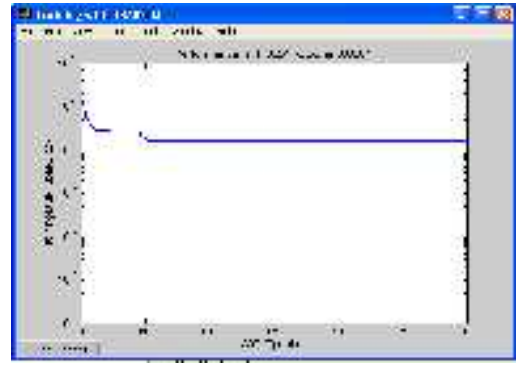

b. Dengan 7 neuron pada lapisan tersembunyi

\section{Gambar 12. Performansi pelatihan untuk 5 dan 7 Neuron pada lapisan tersembunyi}

Dari pelatihan dan simulasi yang dilakukan terhadap jaringan syaraf tiruan dengan 3 neuron pada lapisan tersembunyi seperti terlihat pada kurva gambar 4.11 terlihat bahwa pelatihan yang dilakukan dengan performasi pelatihan (MSE) memberikan menghasilkan yang lebih baik dan cepat. Dengan menetapkan epoch pelatihan 300, pada epoch ke 132 iterasi telah selesai dilakukan dengan goal sebesar 0,0001 .

Ketika disimulasikan dengan data masukan yang sama jaringan syaraf tiruan dapat mendeteksi masukan yang diberikan dengan tepat. Terlihat seluruh hasil simulasi sesuai dengan target yang diharapkan. Akan tetapi ketika dilakukan dengan beberapa data baru yang tidak dilatih sebelumnya, tingkat keberhasilan mendeteksi masukan pada performansi 
MSE lebih baik dari SSE. Dari 17 data baru yang diberikan, pada MSE menghasilkan kesesuaian 13 data (76,47\%) sedangkan SSE menghasilkan kesuaian 9 data $(52,94 \%)$.

Besarnya tingkat kegagalan ini lebih kepada faktor data pelatihan yang relatif masih sedikit. Dalam pengujian ini hanya menggunakan data sebanyak 45 buah data. Namun melihat kepada hasil yang diperoleh ini diyakini bahwa jaringan syaraf buatan ini dapat dimanfaatkan untuk mendeteksi. Disamping itu penetapan nilai pemberat yang secara otomatis oleh Matlab kemungkinan juga bisa memberikan hasil yang berbeda.

Pada pengujian selanjutnya, yaitu dengan 5 dan 7 neuron pada jaringan tersembunyi memperlihatkan keduanya tidak menemukan goal pelatihan hingga akhir epoch (300 epoch), namun ketika dilakukan simulasi dengan data yang sama pada jaringan dengan 5 neuron pada lapisan tersembunyi, memberikan hasil yang cukup baik, dimana dari 45 data yang diuji kembali hanya 1 data yang memberikan hasil yang tidak sesuai. Sementara itu ketika dilakukan simulasi dengan data yang sama dengan data pelatihan pada jaringan dengan 7 neuron pada lapisan tersembunyi kurang memberikan hasil yang memuaskan.
Karena dari 45 data simulasi 18 data tidak dapat dikenal dengan baik.

Ketika disimulasi dengan 17 data baru, jaringan dengan 5 lapisan tersembunyi memberikan hasil yang cukup baik, karena dari 14 dari 17 data simulasi dapat dikenal. Jadi tingkat keberhasilannya adalah 82,35\%. Sementara itu untuk jaringan dengan 7 neuron pada lapisan hasilnya menemukan kesesuai pada 9 data simulasi, jadi keberhasilannya adalah $52,94 \%$.

Berdasarkan uraian diatas maka dapat dilihat bahwa kekurangan masih terlihat pada simulasi ini. Sekali lagi ini kemungkinan besar adalah disebabkan kurangnya data yang digunakan untuk melakukan pelatihan terhadap jaringan yang telah dibentuk. Sedangkan pola jaringan yang memberikan hasil yang agak baik adalah jaringan dengan dengan 3 neuron pada lapisan tersembunyi. Faktor lainnya terjadinya perbedaan dalam penggunaan model lapisan tersembunyi ini tidak stabilnya nilai awal (inisialisasi) yang diberikan pada seluruh pemberat, karena ditetapkan oleh Matlab. Hal ini sesuai dengan yang disebutkan Michael N (2002) bahwa nilai awal dari pemberat akan memberikan hasil pelatihan yang berbeda.

Tabel 3. Data Hasil Pelatihan dan Simulasi dengan data yang sama (3 neuron)

\begin{tabular}{lllllll}
\hline $\mathrm{T}$ & $\begin{array}{l}\text { Output N1 } \\
\text { (MSE) }\end{array}$ & $\begin{array}{l}\text { Output N2 } \\
(\mathrm{SSE})\end{array}$ & $\begin{array}{l}\text { Sim N1 } \\
(\mathrm{MSE})\end{array}$ & $\begin{array}{l}\text { Sim N2 } \\
(\mathrm{SSE})\end{array}$ & $\begin{array}{l}\text { Err N1 } \\
(\mathrm{MSE})\end{array}$ & $\begin{array}{l}\text { Err N2 } \\
(\mathrm{SSE})\end{array}$ \\
\hline 0 & -0.0000 & -0.0000 & -0.0000 & -0.0000 & 0.0000 & 0.0000 \\
0 & 0.0006 & -0.0000 & 0.0006 & -0.0000 & -0.0006 & 0.0000 \\
0 & 0.0003 & -0.0000 & 0.0003 & -0.0000 & -0.0003 & 0.0000 \\
0 & 0.0001 & -0.0000 & 0.0001 & -0.0000 & -0.0001 & 0.0000 \\
0 & 0.0023 & -0.0000 & 0.0023 & -0.0000 & -0.0023 & 0.0000 \\
0 & 0.0001 & -0.0000 & 0.0001 & -0.0000 & -0.0001 & 0.0000 \\
0 & -0.0000 & 0.0002 & -0.0000 & 0.0002 & 0.0000 & -0.0002 \\
1 & 0.9685 & 0.9964 & 0.9685 & 0.9964 & 0.0315 & 0.0036 \\
1 & 0.9946 & 0.9964 & 0.9946 & 0.9964 & 0.0054 & 0.0036 \\
0 & 0.0001 & 0.0001 & 0.0001 & 0.0001 & -0.0001 & -0.0001 \\
0 & -0.0000 & 0.0000 & -0.0000 & 0.0000 & 0.0000 & -0.0000 \\
0 & 0.0001 & -0.0001 & 0.0001 & -0.0001 & -0.0001 & 0.0001 \\
0 & -0.0000 & -0.0004 & -0.0000 & -0.0004 & 0.0000 & 0.0004 \\
0 & -0.0032 & -0.0000 & -0.0032 & -0.0000 & 0.0032 & 0.0000 \\
0 & -0.0016 & 0.0003 & -0.0016 & 0.0003 & 0.0016 & -0.0003 \\
0 & -0.0000 & -0.0001 & -0.0000 & -0.0001 & 0.0000 & 0.0001 \\
\hline
\end{tabular}




\begin{tabular}{|c|c|c|c|c|c|c|}
\hline 0 & 0.0005 & 0.0000 & 0.0005 & 0.0000 & -0.0005 & -0.0000 \\
\hline 0 & -0.0029 & 0.0000 & -0.0029 & 0.0000 & 0.0029 & -0.0000 \\
\hline 0 & 0.0017 & 0.0004 & 0.0017 & 0.0004 & -0.0017 & -0.0004 \\
\hline 0 & -0.0003 & -0.0002 & -0.0003 & -0.0002 & 0.0003 & 0.0002 \\
\hline 0 & -0.0000 & -0.0000 & -0.0000 & -0.0000 & 0.0000 & 0.0000 \\
\hline 1 & 0.9779 & 0.9969 & 0.9779 & 0.9969 & 0.0221 & 0.0031 \\
\hline 0 & -0.0000 & 0.0040 & -0.0000 & 0.0040 & 0.0000 & -0.0040 \\
\hline 0 & -0.0000 & 0.0002 & -0.0000 & 0.0002 & 0.0000 & -0.0002 \\
\hline 0 & 0.0000 & -0.0001 & 0.0000 & -0.0001 & -0.0000 & 0.0001 \\
\hline 0 & -0.0000 & 0.0000 & -0.0000 & 0.0000 & 0.0000 & -0.0000 \\
\hline 0 & 0.0000 & -0.0000 & 0.0000 & -0.0000 & -0.0000 & 0.0000 \\
\hline 0 & -0.0000 & 0.0000 & -0.0000 & 0.0000 & 0.0000 & -0.0000 \\
\hline 1 & 0.9778 & 0.9969 & 0.9778 & 0.9969 & 0.0222 & 0.0032 \\
\hline 0 & 0.0141 & -0.0000 & 0.0141 & -0.0000 & -0.0141 & 0.0000 \\
\hline 0 & -0.0000 & -0.0000 & -0.0000 & -0.0000 & 0.0000 & 0.0000 \\
\hline 0 & -0.0000 & -0.0000 & -0.0000 & -0.0000 & 0.0000 & 0.0000 \\
\hline 0 & 0.0041 & 0.0004 & 0.0041 & 0.0004 & -0.0041 & -0.0004 \\
\hline 1 & 0.9687 & 0.9964 & 0.9687 & 0.9964 & 0.0313 & 0.0036 \\
\hline 0 & 0.0014 & 0.0003 & 0.0014 & 0.0003 & -0.0014 & -0.0003 \\
\hline 0 & -0.0000 & -0.0000 & -0.0000 & -0.0000 & 0.0000 & 0.0000 \\
\hline 1 & 0.9777 & 0.9969 & 0.9777 & 0.9969 & 0.0223 & 0.0031 \\
\hline 0 & -0.0031 & 0.0017 & -0.0031 & 0.0017 & 0.0031 & -0.0017 \\
\hline 0 & -0.0000 & -0.0000 & -0.0000 & -0.0000 & 0.0000 & 0.0000 \\
\hline 0 & -0.0006 & 0.0001 & -0.0006 & 0.0001 & 0.0006 & -0.0001 \\
\hline 0 & -0.0016 & 0.0006 & -0.0016 & 0.0006 & 0.0016 & -0.0006 \\
\hline 0 & -0.0016 & 0.0001 & -0.0016 & 0.0001 & 0.0016 & -0.0001 \\
\hline 0 & -0.0000 & -0.0000 & -0.0000 & -0.0000 & 0.0000 & 0.0000 \\
\hline 0 & -0.0016 & -0.0000 & -0.0016 & -0.0000 & 0.0016 & 0.0000 \\
\hline 1 & 0.9775 & 0.9969 & 0.9775 & 0.9969 & 0.0225 & 0.0031 \\
\hline
\end{tabular}

Tabel 4. Hasil Pelatihan dan Simulasi.dengan 5 dan 7 neuron pada lapisan tersmbunyi dengan data yang sama.

\begin{tabular}{lllllll}
\hline $\mathrm{T}$ & Output N5 & Output N7 & Sim N5 & Sim N7 & Err N5 & Err N7 \\
\hline 0 & -0.0655 & 0.1111 & 0.0389 & 0.1111 & 0.0655 & -0.1111 \\
0 & 0.0000 & 0.1111 & 0.0389 & 0.1111 & -0.0000 & -0.1111 \\
0 & 0.0002 & 0.1111 & 0.1798 & 0.1111 & -0.0002 & -0.1111 \\
0 & 0.0212 & -1.0000 & 0.0014 & -1.0000 & -0.0212 & 1.0000 \\
0 & 0.1176 & -1.0000 & -0.0000 & -1.0000 & -0.1176 & 1.0000 \\
0 & 0.0005 & 0.1111 & 0.0389 & 0.1111 & -0.0005 & -0.1111 \\
0 & 0.0024 & 1.0000 & 0.1798 & 1.0000 & -0.0024 & -1.0000 \\
1 & 1.0000 & 0.1111 & 0.6491 & 0.1111 & 0.0000 & 0.8889 \\
1 & 0.1201 & 1.0000 & 0.5185 & 1.0000 & 0.8799 & 0 \\
0 & -0.0051 & 1.0000 & -0.0177 & 1.0000 & 0.0051 & -1.0000 \\
0 & -0.0205 & 1.0000 & -0.0009 & 1.0000 & 0.0205 & -1.0000 \\
0 & 0.0090 & 1.0000 & -0.0176 & 1.0000 & -0.0090 & -1.0000 \\
0 & 0.1051 & 1.0000 & -0.0177 & 1.0000 & -0.1051 & -1.0000 \\
0 & 0.1304 & 1.0000 & -0.0177 & 1.0000 & -0.1304 & -1.0000 \\
0 & 0.0000 & 1.0000 & 0.5185 & 1.0000 & -0.0000 & -1.0000 \\
0 & 0.0047 & 1.0000 & -0.0000 & 1.0000 & -0.0047 & -1.0000 \\
0 & -0.0063 & 1.0000 & -0.0177 & 1.0000 & 0.0063 & -1.0000 \\
0 & 0.0976 & 1.0000 & 0.0064 & 1.0000 & -0.0976 & -1.0000 \\
0 & 0.0848 & 1.0000 & -0.0165 & 1.0000 & -0.0848 & -1.0000 \\
0 & 0.0809 & -0.0000 & -0.0177 & -0.0000 & -0.0809 & 0.0000 \\
0 & -0.0008 & -0.0000 & -0.0177 & -0.0000 & 0.0008 & 0.0000 \\
1 & 0.9220 & 1.0000 & 1.0000 & 1.0000 & 0.0781 & 0 \\
0 & 0.1299 & 0.1111 & 0.1798 & 0.1111 & -0.1299 & -0.1111 \\
0 & 0.0067 & 0.0000 & 0.0001 & 0.0000 & -0.0067 & -0.0000 \\
0 & 0.1016 & 0.2500 & -0.0177 & 0.2500 & -0.1016 & -0.2500 \\
\hline & & & & & & \\
\hline
\end{tabular}




\begin{tabular}{lllllll}
\hline 0 & 0.0543 & 1.0000 & -0.0174 & 1.0000 & -0.0543 & -1.0000 \\
0 & -0.0146 & 0.1111 & 0.0389 & 0.1111 & 0.0146 & -0.1111 \\
0 & 0.1006 & 1.0000 & -0.0003 & 1.0000 & -0.1006 & -1.0000 \\
1 & 1.0000 & 1.0000 & 0.1798 & 1.0000 & 0.0000 & 0 \\
0 & 0.1377 & 1.0000 & 0.5185 & 1.0000 & -0.1377 & -1.0000 \\
0 & -0.0116 & 0.1111 & 0.1798 & 0.1111 & 0.0116 & -0.1111 \\
0 & 0.0705 & -0.0000 & -0.0177 & -0.0000 & -0.0705 & 0.0000 \\
0 & 0.0797 & 1.0000 & -0.0113 & 1.0000 & -0.0797 & -1.0000 \\
1 & 0.1344 & 1.0000 & 0.6490 & 1.0000 & 0.8656 & 0 \\
0 & 0.0041 & 0.2500 & -0.0177 & 0.2500 & -0.0041 & -0.2500 \\
0 & -0.0100 & -0.0000 & -0.0008 & -0.0000 & 0.0100 & 0.0000 \\
1 & 1.0000 & 1.0000 & 1.0000 & 1.0000 & 0.0000 & 0.0000 \\
0 & 0.1376 & 1.0000 & 0.1798 & 1.0000 & -0.1376 & -1.0000 \\
0 & 0.0528 & 1.0000 & 0.0012 & 1.0000 & -0.0528 & -1.0000 \\
0 & -0.0818 & 0.2500 & -0.0177 & 0.2500 & 0.0818 & -0.2500 \\
0 & 0.1376 & 1.0000 & -0.0177 & 1.0000 & -0.1376 & -1.0000 \\
0 & 0.1377 & 1.0000 & 0.0000 & 1.0000 & -0.1377 & -1.0000 \\
0 & -0.0046 & 0.1111 & 0.1798 & 0.1111 & 0.0046 & -0.1111 \\
0 & 0.1357 & -0.0000 & -0.1593 & -0.0000 & -0.1357 & 0.0000 \\
1 & 0.9766 & 0.2500 & 1.0000 & 0.2500 & 0.0234 & 0.7500 \\
\hline
\end{tabular}

Tabel 4.3. Hasil Pelatihan dan Simulasi.dengan 3, 5 dan 7 neuron pada lapisan tersmbunyi dengan data baru.

\begin{tabular}{lllllllll}
\hline \multirow{2}{*}{$\mathrm{T}$} & Sim N3 & Hsl N3 & Sim N3 & Hsl N3 & \multirow{2}{*}{ Sim N5 } & Hasil & \multirow{2}{*}{ Sim N7 } & Hasil \\
& MSE & MSE & SSE & SSE & & N5 \\
\hline 0 & 0.8364 & TS & -0.2713 & S & -0.0749 & S & -0.0000 & S \\
1 & 0.0014 & TS & -0.2776 & TS & 1.0000 & S & 0.2500 & TS \\
0 & 0.0013 & S & -0.4039 & S & 0.1798 & S & 0.1111 & S \\
0 & -0.0000 & S & 0.6605 & TS & 0.1798 & S & 0.1111 & S \\
0 & -0.6958 & S & 0.9398 & TS & -0.0177 & S & 0.2500 & S \\
0 & -0.0000 & S & 0.8925 & TS & -0.0177 & S & 1.0000 & TS \\
1 & -0.0169 & TS & 0.6748 & S & -0.1593 & TS & 0.2500 & TS \\
0 & -0.9922 & S & 0.6661 & TS & 0.1798 & S & 0.1111 & S \\
0 & -0.0000 & S & 0.7057 & TS & 0.1798 & S & 1.0000 & TS \\
1 & 0.9996 & S & 0.2223 & TS & 0.4065 & TS & 0.1111 & TS \\
1 & -0.0000 & TS & 0.5535 & S & -0.0177 & TS & 0.2500 & TS \\
1 & 0.9688 & S & 0.7734 & S & 0.6491 & S & 1.0000 & S \\
1 & 0.9688 & S & 0.8741 & S & 0.5185 & S & 1.0000 & S \\
0 & -0.9956 & S & -0.7680 & S & 0.1798 & S & 1.0000 & TS \\
1 & 0.9688 & S & 0.6551 & S & 0.6491 & S & 0.1111 & TS \\
1 & 0.9688 & S & 0.8763 & S & 0.5185 & S & 1.0000 & S \\
0 & -0.0000 & S & 0.8009 & TS & -0.1593 & S & -0.0000 & S \\
& & S $=13$ & & S $=9$ & & S $=14$ & & S $=9$ \\
& & $76,47 \%$ & & $52,94 \%$ & & $82,35 \%$ & & $52,94 \%$ \\
\hline
\end{tabular}

Keterangan : $\mathrm{S}=$ Sesuai $\quad \mathrm{TS}=$ Tidak Sesuai

\section{KESIMPULAN}

Berdasarkan hasil analisa dalam penelitian ini dapat diambil kesimpulan sebagai berikut :

- Pixel derau pada citra yang akan dikonvolusi secara sederhana dapat dievaluasi. Dalam penelitian ini ketia digunakan metode seleksi kondisi, memberikan hasil penetapan hanya pada derau dengan ukuran 1 pixel, sehingga hasilnya belum optimal.

- Penggunaan jaringan syaraf tiruan pada penelitian ini hanya 
untuk mendeteksi kemungkinan dikenal atau tidaknya pixel derau. Dari hasil pengujian dengan jaringan syaraf tiruan, keberhasilannya mencapai $82,35 \%$.

- Di antara pola jaringan yang digunakan, jaringan dengan 3 lapisan tersembunyi memberikan hasil 76,47\%, sedangkan pengujian dengan 5 lapisan tersembunyi memberikan hasil sangat baik, $82,35 \%$ dan

- pengujian dengan 7 laspisan tersembunyi memberikan hasil $52,94 \%$

\section{Saran}

- Penyempurnaan dari penelitian ini diharapkan dapat dilanjutkan kearah pemanfaat hasil pendeteksian derau dengan jaringan syaraf tiruan untuk penjernihan citra.

- Untuk memberikan hasil yang lebih baik pembentukan, pelatihan dan simulasi dapat dilakukan dengan menggunakan skrip program Matlab atau bahasa pemrograman lainnya.

- Penggunaan sampel dan jumlah data untuk pelatihan sebaiknya dalam jumlah yang cukup besar

\section{DAFTAR PUSTAKA}

Arief Hemawan, 2006, Jaringan Saraf Tiruan, Teori dan Aplikasi, Penerbit Andi, Yogyakarta.

John O. Moody, Panos J. Antsaklis, The Dependence Identification Neural Network Construction Algorithm, IEEE Transactions on Neural Network Vol.7 No.1, January 1996
Jong Jek Siang, 2005, Jaringan SyarafTiruan Pemrogramannya Menggunakan Matlab, Penerbit Andi, Yogyakarta,

Lee K. Jones, Constructive Approximations for Neural Netwok by Sigmoidal Function, Proceeding of The IEEE Vol. 78 No.10, Oktober 1990

Mauridhi Hery Purnomo, 2002, Dasar Algoritma Cedas, PENS ITS, Surabaya.

Michael Negnevitsky, 2002, Artificial Intelligence, A Guide to Intelligent Systems, Addison Wesley.

Rafael C. Gonzales, Richard E. Woods, 2002, Digital Image Processing, Second Edition, Prentice Hall Inc, New Jersey

Rinaldi Munir, 2004, Pengolahan Citra Digital dengan Pendekatan Algoritma, Penerbit Informatika, Bandung.

Robert C. Williamson, Uwe Helmke, Existence and Uniqueness Results for Neural Network Application, IEEE Transactions on Neual Netwoks Vol. 6 No.1, January 1995

Sri Kusumadewi, 2004, Membangun Jaringan Syaraf Tiruan Menggunakan MATLAB \& EXCELL LINK, Penerbit Graha Ilmu, Yogyakarta. 
ISSN : 2085-6989 